\title{
The impact of sea-level rise on organic matter decay rates in Chesapeake Bay brackish tidal marshes
}

\author{
M. L. Kirwan ${ }^{1}$, J. A. Langley ${ }^{2}$, G. R. Guntenspergen ${ }^{3}$, and J. P. Megonigal ${ }^{4}$ \\ ${ }^{1}$ Department of Environmental Sciences, University of Virginia, Charlottesville, Virginia, USA \\ ${ }^{2}$ Department of Biology, Villanova University, Villanova, Pennsylvania, USA \\ ${ }^{3}$ Patuxent Wildlife Research Center, United States Geological Survey, Laurel, Maryland, USA \\ ${ }^{4}$ Smithsonian Environmental Research Center, Edgewater, Maryland, USA
}

Correspondence to: M. L. Kirwan (mlk4n@virginia.edu)

Received: 18 September 2012 - Published in Biogeosciences Discuss.: 22 October 2012

Revised: 18 February 2013 - Accepted: 5 March 2013 - Published: 19 March 2013

\begin{abstract}
The balance between organic matter production and decay determines how fast coastal wetlands accumulate soil organic matter. Despite the importance of soil organic matter accumulation rates in influencing marsh elevation and resistance to sea-level rise, relatively little is known about how decomposition rates will respond to sea-level rise. Here, we estimate the sensitivity of decomposition to flooding by measuring rates of decay in 87 bags filled with milled sedge peat, including soil organic matter, roots and rhizomes. Experiments were located in field-based mesocosms along 3 mesohaline tributaries of the Chesapeake Bay. Mesocosm elevations were manipulated to influence the duration of tidal inundation. Although we found no significant influence of inundation on decay rate when bags from all study sites were analyzed together, decay rates at two of the sites increased with greater flooding. These findings suggest that flooding may enhance organic matter decay rates even in water-logged soils, but that the overall influence of flooding is minor. Our experiments suggest that sea-level rise will not accelerate rates of peat accumulation by slowing the rate of soil organic matter decay. Consequently, marshes will require enhanced organic matter productivity or mineral sediment deposition to survive accelerating sea-level rise.
\end{abstract}

\section{Introduction}

Coastal marshes are among the most productive ecosystems on Earth. Net primary productivity in temperate regions commonly exceeds $800 \mathrm{~g} \mathrm{C} \mathrm{m}^{-2} \mathrm{yr}^{-1}$ (Mendelssohn and Morris,
2000), allowing vegetated marshes to protect coastal regions by dissipating energy associated with storms, trap mineral sediment and pollutants, support marine fisheries, and sequester carbon (Zedler and Kercher, 2005). Because organic matter accumulation is an important mechanism regulating marsh elevation in many marshes (Nyman et al., 1993, 2006; Turner et al., 2000; Cahoon et al., 2006; Langley et al., 2009; Drexler, 2011), the fate of these ecosystem services under future sea-level rise depends largely on the balance between organic matter production and decay.

The factors controlling organic matter production are generally well studied (Turner, 1976; Mendelssohn and Morris, 2000; Kirwan et al., 2009). Recent work suggests that rates of productivity are maximized at some optimum flooding frequency or rate of sea-level rise (Morris et al., 2002; Kirwan and Guntenspergen, 2012; Voss et al., 2013; Langley et al., 2013; though also see Marani et al., 2004; Kirwan et al., 2012), where moderate increases in flooding lead to flushing of salts, delivery of nutrients, and enhanced productivity. At higher rates of sea-level rise, and for longer durations of inundation, the accumulation of sulfides under anaerobic conditions limits rates of productivity (e.g. Mendelssohn and Morris, 2000; Morris et al., 2002; Marani et al., 2004; Kirwan et al., 2012).

Much less is known about how sea-level rise and flooding frequency will influence soil organic matter (SOM) decomposition. Although a reduction in decay rate associated with progressively more anaerobic soils is often assumed (e.g. Nyman and DeLaune, 1991; Reed, 1995; Miller et al., 2001), attempts to measure decay rates in coastal wetlands have led 
to a wide range of conclusions. In freshwater marshes, decomposition rates near the soil surface tend to increase with flooding duration (Ewel and Odum, 1978; Mendelssohn et al., 1999), even though decomposition rates decline with soil depth and its effect on redox potential (Mendelssohn et al., 1999; Pozo and Colino, 1992). Responses in salt marshes are also variable. Nyman and DeLaune (1991), for example, measured reduced soil respiration rates in more flooded environments, but several authors have concluded that flooding frequency and redox potential play only minor roles in determining organic decay rates (Valiela et al., 1982; Hackney, 1987; Blum, 1993; Blum and Christian, 2004). Such a conclusion is perhaps surprising when viewed in the context of experiments conducted in terrestrial ecosystems. Decomposition rates in swamp forests and riparian systems tend to increase with flooding duration (Brinson, 1977; Capps et al., 2011 and references therein), although this effect can be confounded with changes in the chemical characteristics of leaf litter that vary with species composition across flooding gradients (Day, 1979). Similarly, groundwater table elevation (and consequent redox potential) is a primary influence on organic matter decay in terrestrial peat bogs (Ise et al., 2008; Broder et al., 2012). Other work in terrestrial environments may offer a unifying perspective. Where decomposition takes place in dominantly aerobic conditions, periodic flooding may increase soil moisture and microbial activity, whereas excessive flooding creates anaerobic conditions that limit decomposition (Neckles and Neill, 1994).

An important limitation of the existing literature on decomposition responses to changes in hydroperiod is the fact that most studies have measured decay on recently senesced organic matter such as leaf litter. Decay rates in the early stages of decomposition do not necessarily predict rates at later stages of decomposition (e.g. Day, 1979), particularly the fraction of plant production that ultimately contributes to elevation due to preservation such as SOM. Thus, forecasting the effects of sea-level rise on elevation requires quantifying effects on SOM decomposition. Here, we measured SOM decomposition rates in three Chesapeake Bay brackish marshes where flooding frequency varies along an experimentally manipulated elevation gradient, and found decay rates to be largely insensitive to flooding frequency.

\section{Methods}

\subsection{Study area}

We measured decomposition rates of soil organic material in three sites along tributaries of the Chesapeake Bay (Maryland, USA), including the Rhode River $\left(38.87472^{\circ} \mathrm{N}, 76.54639^{\circ} \mathrm{W}\right)$, Blackwater River $\left(38.40434^{\circ} \mathrm{N}, 76.07302^{\circ} \mathrm{W}\right)$, and Transquaking River $\left(38.38445^{\circ} \mathrm{N}, 76.00159^{\circ} \mathrm{W}\right.$ ) (Fig. 1). All three sites are mesohaline with long-term average porewater salinities of

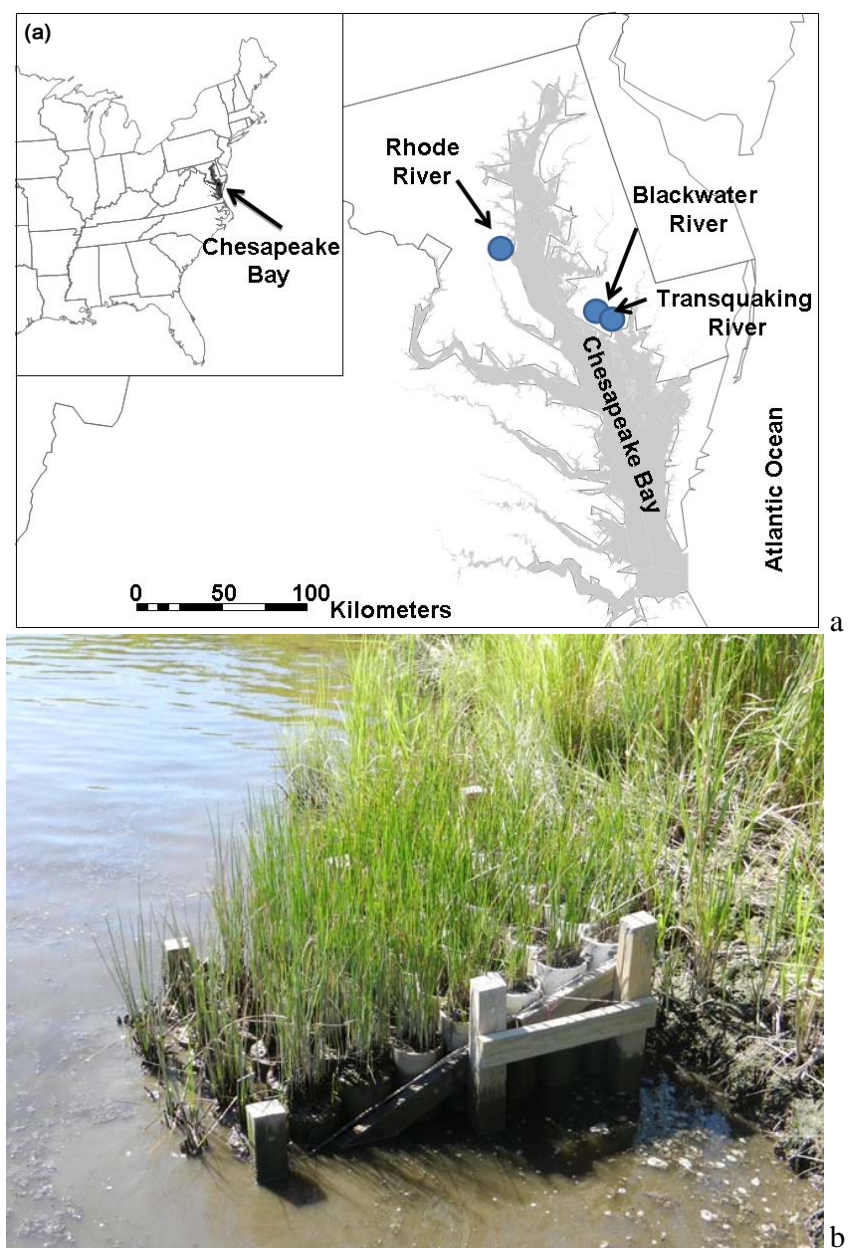

Fig. 1. Map of experiment locations (a) and photograph of experimental elevation platform at low tide in a tributary tidal creek of the Transquaking River (b).

10 at Blackwater and Rhode River sites, and 12 at the Transquaking River site. Each site is dominated by a similar set of intertidal macrophytes, including Schoenoplectus americanus, Spartina patens, Distichlis spicata, and Phragmites australis. Meteorological events strongly influence water levels at the Rhode and Blackwater locations (astronomical tides $<50 \mathrm{~cm}$ ), while the Transquaking location has an astronomical tidal range of approximately $1 \mathrm{~m}$. The elevation of the marsh adjacent to our experiments is approximately 10-15 cm NAVD (North American Vertical Datum) at the Blackwater site, $25-35 \mathrm{~cm}$ NAVD at the Transquaking site, and $15-35 \mathrm{~cm}$ NAVD at the Rhode River site. NAVD approximates mean sea level $( \pm 10 \mathrm{~cm})$ in the Chesapeake region (Hensel et al., 2008).

\subsection{Experimental design}

At each site, we constructed platforms ("marsh organs") containing mesocosms at different elevations to simulate the response of plant growth to different flooding regimes 
(Kirwan and Guntenspergen, 2012; Langley et al., 2013) (Fig. 1b). Mesocosms in the Blackwater and Transquaking platforms consisted of $15 \mathrm{~cm}$ diameter $\left(182 \mathrm{~cm}^{2}\right)$ PVC pipe, filled with native sediment. We transplanted $15 \mathrm{~cm}$ deep sods of native marsh soil and vegetation (Schoenoplectus americanus or Spartina patens) into each pipe. Mesocosms in the Rhode River platforms consisted of $10 \mathrm{~cm}$ diameter PVC pipe, filled with commercial sedge peat similar to natural high marsh peat soils ( $80 \%$ organic matter) at this site. Here, plants were propagated from rhizome fragments or seed collected from the Rhode River site, planted in pipes and allowed to acclimate before sea-level treatments were initiated. This approach to sea-level manipulation attempts to isolate the effect of hydroperiod from other variables (e.g. salinity, substrate composition) that would co-vary along a natural elevation gradient. In reality, variables such as soil salinity may covary with elevation in ways that approximate natural patterns (e.g. soil salinity in frequently flooded, low elevation mesocosms is controlled by the salinity of flood waters, whereas salinity of high elevation mesocosms varies with precipitation and evaporation). We did not measure salinity, but acknowledge that it has an important influence on decay (Craft, 2007; Weston et al., 2011; Sutton-Grier and Megonigal, 2011). We have previously reported the effect of elevation on plant growth from these experiments (Kirwan and Guntenspergen, 2012; Langley et al., 2013).

Here we consider the effect of elevation and hydroperiod on the decomposition rate of soil organic matter (SOM) using the method of Weiss et al. (2005). SOMbags were constructed from a non-reactive synthetic membrane $\left(\right.$ Versapor $^{\circledR}$; Pall Corporation, Port Washington, NY) with a $5 \mu \mathrm{m}$ pore size to allow adequate flow of water and access to microbes, but to restrict the passage of soil particles. Each bag was approximately $6 \times 4 \times 1 \mathrm{~cm}$, and filled with $2.0-2.5 \mathrm{~g}$ of peat harvested from the Rhode River site at a depth of $0-20 \mathrm{~cm}$. Peat was removed from the site, air dried, and milled to homogenize so that variability in SOM quality among bags was minimized. The bags were heatsealed, placed in a water bath subjected to $12 \mathrm{~h}$ of agitation to test durability and remove readily soluble components. Bags were then oven dried at $40^{\circ} \mathrm{C}$ to determine the initial mass of dry peat. The same peat was used at each site to control for variation in carbon quality (e.g. Day, 1979), allowing for an intercomparison of physiochemical decomposition environments among sites. Bags were placed in randomly selected mesocoms, and oriented vertically so that peat in each bag extended from the soil surface to a depth of approximately $5-10 \mathrm{~cm}$ beneath the surface. At each site we recorded water levels in the tidal creek with pressure transducers and calculated the frequency and duration of inundation for each mesocosm elevation. Inundation in a given row occurs when the water level in the creek is higher than the elevation of the mesocosm, and we report only the duration of inundation averaged over the entire experiment.
Table 1. Summary of decomposition experiments in 3 tributary rivers of the Chesapeake Bay. $n$ refers to the number of undamaged bags retrieved at the end of the experiment, and therefore included in the decay analysis. Average decay represents a simple arithmetic mean of all measured decay coefficients, $k$, in each experiment and includes the standard deviation.

\begin{tabular}{llrrr}
\hline Experiment & $\begin{array}{l}\text { Deployment } \\
\text { dates }\end{array}$ & $n$ & $\begin{array}{r}\text { Elevation } \\
\text { range } \\
\left(\mathrm{cm} \mathrm{NAVD}^{2}\right.\end{array}$ & $\begin{array}{r}\text { Average } \\
\text { decay, } \\
k\left(\mathrm{yr}^{-1}\right)\end{array}$ \\
\hline Rhode 10 & 1 May-1 Sep 2010 & 27 & $-16-49$ & $0.30 \pm 0.04$ \\
Rhode 11 & 1 May-1 Sep 2011 & 13 & $-16-29$ & $0.23 \pm 0.03$ \\
Blackwater 1 & 1 June-16 Aug 2011 & 19 & $-5-47$ & $0.19 \pm 0.08$ \\
Blackwater 2 & 1 June-16 Aug 2011 & 19 & $-5-34$ & $0.19 \pm 0.08$ \\
Transquaking & 2 June-17 Aug 2011 & 9 & $11-39$ & $0.21 \pm 0.06$ \\
\hline
\end{tabular}

Decomposition experiments were conducted at each site, but over different time intervals and elevation ranges $(\mathrm{Ta}-$ ble 1). At the Rhode River site, SOMbags were deployed in a single platform in 2 consecutive years (1 May-1 September 2010, 1 May-1 September 2011). At the Blackwater River site, SOMbags were deployed during a single year, but in two platforms (1 June-16 August 2011). Experiments at the Transquaking River site were during a single year and in a single platform (2 June-17 August 2011). A total of 97 SOMbags were deployed. At the end of each experiment, bags were retrieved, dried at $40^{\circ} \mathrm{C}$, and weighed. Eight ripped SOMbags and two bags with apparent weight gain (presumably from analytical error and/or the introduction of exogenous material) were discarded, leaving a total of 87 bags used in the analysis. To account for differences that may have arisen from processing samples in two different laboratory conditions, a subset of the Blackwater \& Transquaking River samples processed at the USGS laboratory were oven dried and desiccated at Villanova University where Rhode River samples were analyzed; a small correction (3\% of final mass) was applied so that all initial and final masses are directly comparable.

\subsection{Analytical methods}

Decomposition of organic material typically follows an exponential decay function, where the rate of mass loss $(\mathrm{d} C / \mathrm{d} t)$ is proportional to the mass of organic material remaining $(C), \mathrm{d} C / \mathrm{d} t=-k C$. Consequently, we express mass loss in terms of the decay coefficient $(k)$ to account for differences in deployment duration and variation in initial peat weight. Following Olsen (1963), $k=\left[-\ln \left(C_{t} / C_{\mathrm{o}}\right)\right] / t$ where $C_{\mathrm{o}}$ and $C_{t}$ are the mass of organic matter at the beginning and end of the experiment, and $t$ is the duration of the experiment. Subsamples of initial and decayed peat from the Blackwater and Rhode River sites were analyzed on a Carlo Erba elemental analyzer (Milan, Italy) coupled to a Finnegan Delta Plus mass spectrometer (Bremen, Germany) for carbon and nitrogen composition to determine if exogenous material 

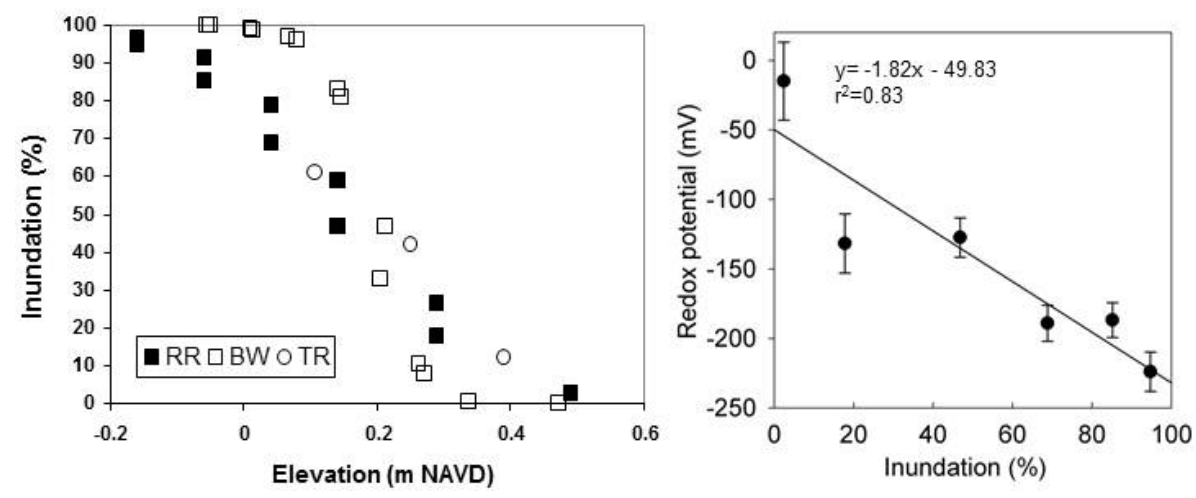

Fig. 2. Influence of mesocosm elevation on physical properties during decomposition experiments. (a) Flooding duration expressed as the percentage of time flooded at each site. Legend abbreviations refer to Rhode River (RR), Blackwater River (BR) and Transquaking River (TR) sites (b) soil redox potential at the Rhode River site.

had entered the bags and to assess organic matter $\mathrm{N}$ dynamics. Percent change in $\mathrm{C}$ and $\mathrm{N}$ content was calculated per the following: $100 \cdot\left(\right.$ litter mass final $\left.\times[\mathrm{C}]_{\text {final }}\right)-($ litter $\left.\operatorname{mass}_{\text {initial }} \times[\mathrm{C}]_{\text {initial }}\right) /\left(\right.$ litter mass initial $\left.\times[\mathrm{C}]_{\text {initial }}\right)$.

Rates of mass loss and decay coefficients were related to the duration of inundation during the experiment using simple linear regression and calculating Pearson linear correlation coefficients. Statistical treatments were performed on individual bags unless otherwise noted. For example, replicate bags at each elevation were averaged together for each site in one analysis. This approach tends to minimize variability associated with subtle differences in individual mesocosms (e.g. differences in shading or soil properties), allowing us to isolate the effect of flooding on decay rate, and to better detect potential differences between sites. Finally, we combined $[\mathrm{C}]$ and $[\mathrm{N}]$ data from the Blackwater and Rhode River sites to look for generality in decay patterns across sites and flooding conditions.

\section{Results}

Variations in mesocosm elevation resulted in a gradient in tidal inundation, where the highest rows of the platforms were never flooded, the lowest rows were always inundated, and intermediate elevations captured the full range of tidal inundation (Fig. 2a). Redox potential at the Rhode River site varied between -20 and $-225 \mathrm{Eh}$ and was significantly correlated with mesocosm elevation (Fig. 2b; $r=0.95 ; p=0.011$ ). Although redox was not measured at the Blackwater and Transquaking River sites, field observations suggest a similar pattern. Decomposition bags were stained with iron oxides at high elevations, and all live plant roots died at the permanently flooded low elevations (Kirwan and Guntenspergen, 2012), suggesting a transition from aerobic soils to anaerobic soils.

SOMbags lost between 1 and $12 \%$ of initial mass in the experiments, resulting in decay coefficients between 0.04 and $0.38 \mathrm{yr}^{-1}$ (Fig. 3a). Bags contained no visible live roots, and nutrient analysis indicated little contamination by exogenous mineral sediment (the average final [C] was $98.9 \%$ of the initial [C]). Decay rates tended to be higher at the Rhodes River site than at the Blackwater and Transquaking River sites [Table 1, Fig. 3b]. When replicate bags at identical elevations were averaged together, decay rates were positively correlated with inundation duration at the Blackwater $(r=0.533 p=0.050)$ and Transquaking River sites $(r=0.977 p=0.138)$, but not at the Rhodes River site $(r=-0.331 p=0.281)$, or when all 3 sites were considered together $(r=0.237 p=0.216)$ (Fig. 3b). A two-way ANOVA with inundation duration as a categorical variable confirmed that site location rather than inundation is a significant determinant of decay rate, and that there is no interactive effect.

The remaining SOM in the majority of bags had lower [C] and higher $[\mathrm{N}]$ than the initial SOM (Fig. 4a, c). Remaining SOM $[\mathrm{N}]$ declined with increasing inundation $(r=0.422$, $p=0.015)$. Remaining $\mathrm{C}$ and $\mathrm{N}$ mass in litter exhibited quadratic responses to inundation ( $\mathrm{C}: r=0.436, p=0.043$; $\mathrm{N}: r=0.494, p=0.015$ ), such that SOM exposed to intermediate flooding exhibited the greatest $\mathrm{C}$ loss and the least $\mathrm{N}$ loss.

\section{Discussion}

We have made several important assumptions in our attempt to design a simple experiment that isolates the effect of inundation and sea-level rise on the decomposition rate of organic material. The most significant assumption is that the design of the mesocosm platforms at least approximates how wetland soils will respond to rising sea levels and increasing periods of inundation. For example, we recognize that drainage in a soil surrounded by PVC pipe likely differs from drainage in a natural marsh. Although vertical exchanges of water dominate flow paths in marshes (Nuttle, 1988), they are the 
a)

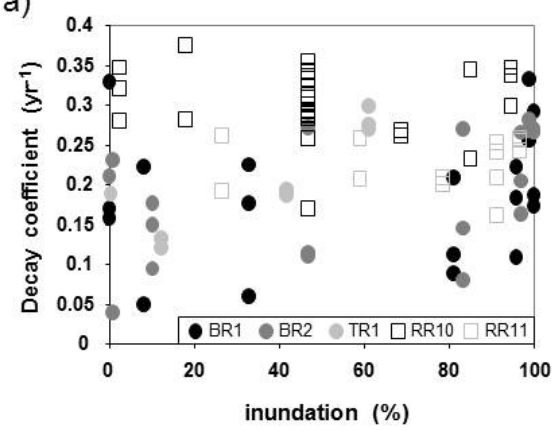

b)

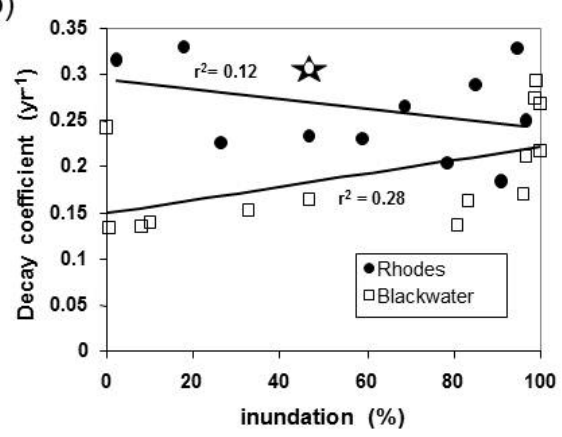

Fig. 3. Litter decay rate as a function of inundation duration. (a) Decay coefficients $(k)$ of individual litter bags where markers refer to Blackwater River experiment 1, Blackwater River experiment 2, Transquaking River experiment 1, Rhode River experiment in 2010, and Rhode River experiment in 2011. (b) Decay coefficients $(k)$ where replicate SOMbags at each elevation have been averaged together. For simplicity, Transquaking River data are not plotted. Star denotes the average decay rate for bags placed in the marsh adjacent to the Rhode River experiment.

a)
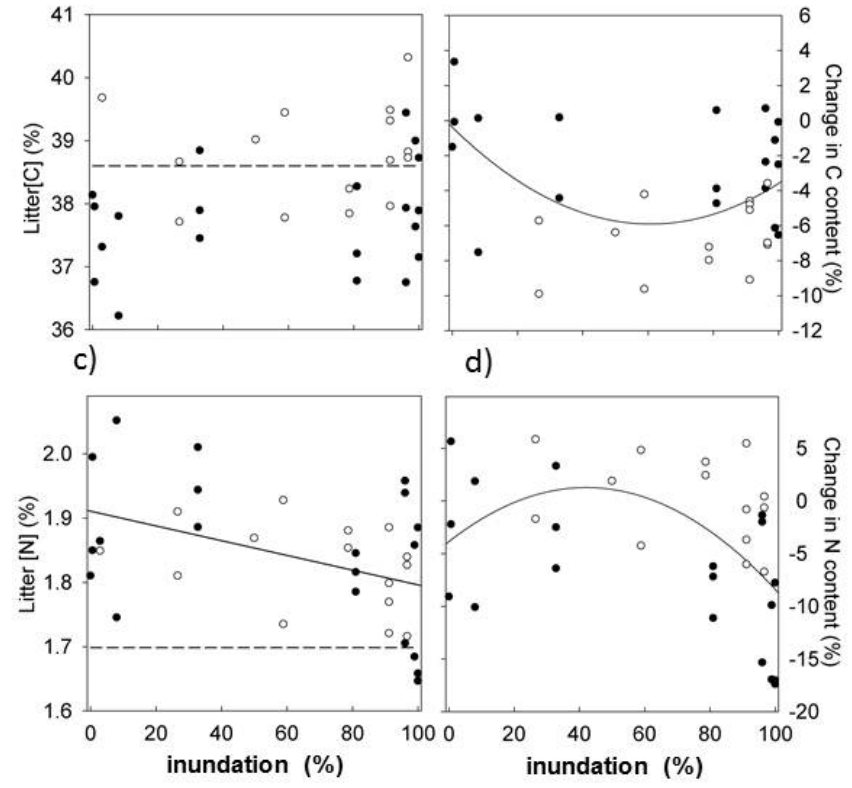

Fig. 4. $\mathrm{C}$ and $\mathrm{N}$ concentrations of decomposing litter (left) and change in $\mathrm{C}$ and $\mathrm{N}$ mass during decomposition (right). Filled circles represent results from the Blackwater River site, and open circles represent results from the Rhode River site. Dashed lines in left panels indicate initial concentration of $\mathrm{C}$ and $\mathrm{N}$. Solid lines denote trends between flooding duration and element concentration or mass loss. Regressions correspond to data from both sites, although the relationship between $\mathrm{N}$ loss and inundation is also signficant at the Blackwater site alone (not shown). Significant relationships: (b) $y=0.002 x^{2}-0.182 x-0.387$, $r^{2}=0.19, p=0.04 ;$ (c) $y=-0.001 x+1.91, r^{2}=0.18, p=0.01$; (d) $y=-0.003(x)^{2}-0.243 x-3.837, r^{2}=0.24, p=0.015$.

only source of inundation and drainage in our experiments (i.e. no horizontal flow) (Kirwan and Guntenspergen, 2012). Moreover, our experimental mesocosms lack the spatial het- erogenity (e.g. in hydraulic conductivity) that plays a role in determining whether inundation is accomodated by ponding or drainage. Previous experiments with these elevation platforms demonstrate that the relative sensitivity of different plant species to flooding resembles plant zonation patterns in natural marshes, suggesting that some of the important characteristics of natural marshes may be captured (Kirwan and Guntenspergen, 2012). Furthermore, independent measurements of decay from marshland adjacent to the Rhode River experiment resemble rates of decay measured in mesocosms at similar elevation, suggesting that our results are not strongly influenced by artifacts of the experimental design (star symbol in Fig. 3b, representing an average of 13 replicate bags deployed in the 2010 experiment). We also assume that material in the SOMbags decay at rates similar to in-situ belowground material, and that the fine membrane used to construct the SOMbags does not limit decay (e.g. through the exclusion of invertebrates). Moreover, live roots may stimulate decomposition by releasing $\mathrm{O}_{2}$ into anaerobic soils, but were excluded from direct contact with decaying material by the SOMbag membrane (Hackney and de la Cruz, 1980; McKee et al., 1988; Havens, 1997; Wolf et al., 2007). The range of decay coefficients we measured $\left(0\right.$ to $\left.0.376 \mathrm{yr}^{-1}\right)$ was slightly lower than ranges of decay measured elsewhere in the mid-Atlantic for S. alterniflora and Juncus roemerianus roots and rhizomes ( 0.11 to $0.51 \mathrm{yr}^{-1}$ ) (Blum and Christian, 2004) and for newly senescent $P$. australis and $S$. patens litter $\left(0.25\right.$ to $\left.0.57 \mathrm{yr}^{-1}\right)$ (Windham, 2001), suggesting that our experimental approach captured the well-documented decline in decay rates across the continuum from fresh litter to SOM.

Our results are consistent with previous work in salt marshes that indicates decomposition rates are not strongly related to flooding duration and soil redox potential (Valiela et al., 1982; Hackney, 1987; Blum, 1993; Blum and Christian, 2004). Moreover, Blum (1993) concludes that the insensitivity means that differences in organic matter 
accumulation between high and low marsh areas must be explained by differences in root production rather than differences in decay. Our results support these observations, and suggest that the concepts may additionally be applicable to mesohaline wetlands. Applicability to marshes with lower salinities is an important insight because salinity may play a fundamental role in determining the rate of organic matter decay (Weston et al., 2011; Sutton-Grier and Megonigal, 2011) such that elevation changes in fresh and brackish marshes tend to be dominated by root zone processes, and to accumulate organic matter faster than more saline wetlands (Craft, 2007).

However, we also find an unexpected positive relationship between flooding and decay rates at two of our study sites. Intermittent flooding typically enhances the decay of litter at the soil surface in ecosystems with mostly aerobic soil surfaces such as riparian forests, prairie wetlands, and freshwater marshes (Brinson, 1977; Day, 1979; Ewel and Odum, 1978; Maltby, 1988; Mendelssohn et al., 1999; Neckles and Neill, 1994). In these ecosystems, flooding may accelerate the leaching and microbial decomposition phases of organic matter decay by providing moisture and nutrients to microbial and fungal communities (Bragazza et al., 2012; Neckles and Neill, 1994). However, decomposition generally occurs more rapidly in aerobic soils than anaerobic soils, and positive relationships between flooding and decay rate observed near the soil surface tend to disappear with soil depth (e.g. Mendelssohn, 1999; Neckles and Neill, 1994). Therefore, our finding that decay rates at the Blackwater and Transquaking River sites continue to increase with flooding even in permanently saturated soils is surprising. Delivery of oxygen via live roots (e.g. Wolf et al., 2007) is not a possible explanation because the lowest elevation mesocosms did not support root growth in these experiments (Kirwan and Guntenspergen, 2012). Instead, we hypothesize that delivery of terminal electron acceptors (i.e. sulfate) and nutrients by tidal inundation may have accelerated decomposition rates, but acknowledge that the steady increase in decay rate is difficult to explain.

The lack of consistent inundation effect on mass loss could be an artifact of our SOMbag method. Measured changes in mass are small relative to the total mass of soil in each bag, perhaps limiting the ability to detect subtle trends over error implicit in the experimental design. Potential sources of error include small differences in moisture content arising from differences in lab humidity, mass loss of the bags themselves, or the input of exogenous material $(<5$ micron) into the bags. Changes in the total mass of $\mathrm{C}$ and $\mathrm{N}$ in the SOMbags may provide an alternative indication of biological decomposition that is insensitive to changes in mineral or water content, obviating some of the error associated with measuring decomposition by mass loss. Most plant-derived litter undergoes a brief initial period of $\mathrm{N}$ loss from physio-chemical leaching followed by a phase of net $\mathrm{N}$ gain from microbial immobilization (Jordan et al., 1989). Therefore, accelerated decay should result in a decline of $\mathrm{C}$ mass and likely an increase of $\mathrm{N}$ mass. In our experiments, most samples exhibited reduced [C] and increased [N] (Fig. 4), suggesting these chemical indicators may indeed reflect biological decomposition. The changes in $\mathrm{C}$ and $\mathrm{N}$ mass (the product of concentrations and masses) indicate optimum decomposition at intermediate flooding durations. C loss was maximal in mesocosms that were flooded $60 \%$ of the time, and $\mathrm{N}$ loss was greatest at a similar flooding regime ( $40 \%$ inundation). Although undetectable in simple mass loss measurements, the existence of an optimum flooding frequency for organic decay could help rectify patterns of enhanced decay with flooding in rarely flooded marshes (e.g. Mendelssohn et al., 1999), and reduced decay with flooding in more regularly flooded wetlands (i.e. Nyman and DeLaune, 1991). If robust, these results suggest that marshes losing elevation to sea-level rise could experience reduced rates of organic matter decay as their elevation becomes deeper in the tidal frame. Nevertheless, the effects of flooding on decomposition measured by changes in element concentration were small relative to unexplained variance $\left(r^{2}=0.19\right.$, Fig. $\left.4 \mathrm{~b}\right)$, and the relationships difficult to discern in either method.

The adaptability of coastal wetlands to sea-level rise is often attributed, in part, to the idea that flooding will slow rates of organic matter decay and facilitate more rapid organic matter accumulation (Nyman and DeLaune, 1991; Reed, 1995; Miller et al., 2001). In contrast, our measurements of mass loss suggest that enhanced flooding will lead to little change in decay rate, at least in these brackish marshes. Therefore, our results suggest that any adaptation of marshes to sea-level rise must be accomplished through enhanced root production (e.g. Langley et al., 2009; Kirwan and Guntenspergen, 2012) or mineral sedimentation (e.g. Morris et al., 2002). Since many of the wetlands most susceptible to sea-level rise are deficient of mineral sediment (e.g. Kirwan et al., 2010; Day et al., 2011), we suggest that once the primary productivity of a marsh starts to decline, sustained and perhaps accelerated rates of decomposition will only exacerbate the syndrome through loss of elevation.

Acknowledgements. This work was supported by the USGS Global Change Research Program. We appreciate the efforts of R. Kyle Derby and Patrick Brennand in conducting field work. Any use of trade, product, or firm names is for descriptive purposes only and does not imply endorsement by the US Government.

Edited by: C. P. Slomp

\section{References}

Blum, L. K.: Spartina-Alterniflora Root Dynamics in a Virginia Marsh, Mar. Ecol.-Prog. Ser., 102, 169-178, 1993.

Blum L. K. and Christian, R. R.: Belowground production and decomposition along a tidal gradient in a Virginia salt marsh, in: The Ecogeomorphology of Tidal Marshes, edited by: Fagherazzi, 
S., Marani, M., and Blum, L. K., American Geophysical Union, Washington DC, 2004.

Bragazza L., Buttler, A., Habermacher, J., Brancaleoni, L., Gerdol, R., Fritze, H., Hanajik, P., Laiho R., and Johnson, D.: High nitrogen deposition alters the decomposition of bog plant litter and reduces carbon accumulation, Global Change Biol., 18, 11631172, 2012.

Brinson, M. M.: Decomposition and nutrient exchange of litter in an alluvial swamp forest, Ecology, 58, 601-609, 1997.

Broder, T., Blodau, C., Biester, H., and Knorr, K. H.: Peat decomposition records in three pristine ombrotrophic bogs in southern Patagonia, Biogeosciences, 9, 1479-1491, doi:10.5194/bg9-1479-2012, 2012.

Capps, K. A., Graca, M. A. S., Encalada, A. C., and Flecker, A. S.: Leaf-litter decomposition across three flooding regimes in a seasonally flooded Amazonian watershed, J. Trop. Ecol., 27, 205210, 2011

Cahoon, D. R., Hensel, P. F., Spencer, T., Reed, D. J., McKee, K. L., and Saintilan, N.: Coastal wetland vulnerability to relative sea-level rise: wetland elevation trends and process controls, in: Wetlands and Natural Resource Management: Ecological Studies, edited by: Verhoeven J. T. A, Beltman, B., Bobbink, R., and Whigham, D. F., 190, 271-292, 2006.

Craft, C.: Freshwater input structures soil properties, vertical accretion, and nutrient accumulation of Georgia and U.S. tidal marshes, Limnol. Oceanogr., 52, 1220-1230, 2007.

Day, F. P.: Litter accumulation in four plant communities in the Great Dismal Swamp, Virginia, Am. Midl. Nat., 102, 281-289, 1979.

Day, J., Ibanez, C., Scarton, F., Pont, D., Hensel, P., Day, J., and Lane, R.: Sustainability of Mediterranean deltaic and lagoon wetlands with sea-level rise: The importance of river input, Estuar. Coast., 34, 483-493, 2011.

Drexler, J. Z.: Peat Formation Processes Through the Millennia in Tidal Marshes of the Sacramento - San Joaquin Delta, California, USA, Estuar. Coast., 34, 900-911, 2011.

Ewel, K. C. and Odum, H. T.: Cypress domes: nature's tertiary treatment filter, in: Cypress wetlands for water management, recycling and conservation, edited by: Odum, H. T. and Ewel, K. C., Fourth Annual Report to NSF-RANN and the Rockefeller Foundation, Gainesville, FL: 35-60, 1978.

Hackney, C. T.: Factors affecting accumulation or loss of macroorganic matter in salt marsh sediments, Ecology, 68, 1109-1113, 1987.

Hensel, P. F., Scott, G. A., Allen, A. L., Gill, S. K., Cahoon, D. R., Nemerson, D., and Guntenspergen, G. R.: Geodetic and tidal datums: tying wetland surface elevation change to local water levels, 2008 Ocean Sciences Meeting Abstract, American Geophysical Union, Orlando FL, 2008.

Ise, T., Dunn, A. L., Wofsy, S. C., and Moorcroft, P. R.: High sensitivity of peat decomposition to climate change through watertable feedback, Nat. Geosci., 1, 763-766, 2008.

Jordan T. E., Whigham D. F., and Correll D. L.: The role of litter in nutrient cycling in a brackish tidal marsh, Ecology, 70, 19061915, 1989.

Kirwan, M. L. and Guntenspergen, G. R.: Feedbacks between inundation, root production, and shoot growth in a rapidly submerging brackish marsh, J. Ecol., 100, 764-770, 2012.
Kirwan, M. L., Guntenspergen, G. R., and Morris J. T.: Latitudinal trends in Spartina alterniflora productivity and the response of coastal marshes to global change, Global Change Biol., 15, 1982-1989, 2009.

Kirwan, M. L., Guntenspergen, G. R., D’Alpaos, A., Morris, J. T., Mudd, S. M., and Temmerman, S.: Limits on the adaptability of coastal marshes to rising sea Level, Geophys. Res. Lett., 37, L23401, doi:10.1029/2010GL045489, 2010.

Kirwan, M. L., Christian, R. R., Blum, L. K., and Brinson, M. M.: On the relationship between sea level and Spartina alterniflora production, Ecosystems, 15, 140-147, 2012.

Langley, J. A., Mckee, K. L., Cahoon, D. R., Cherry, J. A., and Megonigal, J. P.: Elevated $\mathrm{CO}_{2}$ stimulates marsh elevation gain, counterbalancing sea-level rise, Proc. Natl. Acad. Sci. USA, 106, 6182-6186, 2009.

Langley, J. A., Mozdzer, T. J., Shepard, K. A., Hagerty, S. B., and Megonigal, J. P.: Tidal marsh plant responses to elevated $\mathrm{CO}_{2}$, nitrogen fertilization, and sea level rise, Global Change Biol., in press, doi:10.1111/gcb.12147, 2013.

Maltby, E.: Use of cotton strip assay in wetland and upland environments- an international perspective, in: Cotton strip assay: An index of decomposition in soils, edited by: Harrison, A. F., Latter, P. M., and Walton, D. W. H., Institute of Terrestrial Ecology, Grange-Over-Sands, UK, 140-154, 1988.

Marani, M., Lanzoni, S., Silvestri, S., and Rinaldo, A.: Tidal landforms, patterns of halophytic vegetation and the fate of the lagoon of Venice, J. Marine Syst., 51, 191-210, 2004.

Mendelssohn, I. A. and Morris, J. T.: Eco-physiological controls on the productivity of Spartina alterniflora Loisel, in: Concepts and Controversies in Tidal Marsh Ecology, edited by: Weinstein, M. P. and Kreeger, D. A., 59-80, Kluwer Academic Publishers, Netherlands, 2000.

Mendelssohn, I. A., Sorrell, B. K., Brix, H., Schierup, H. H., Lorenzen, B., and Maltby, E.: Controls on soil cellulose decomposition along a salinity gradient in a Phragmites australis wetland in Denmark, Aquat. Bot., 64, 381-398, 1999.

Miller, W. D., Neubauer, S. C., and Anderson, I. C.: Effects of sea level induced disturbance on high salt marsh metabolism, Estuaries, 24, 357-367, 2001.

Morris, J. T., Sundareshwar, P. V., Nietch, C. T., Kjerfve, B., and Cahoon, D. R.: Responses of coastal wetlands to rising sea level, Ecology, 83, 2869-2877, 2002.

Neckles, H. A. and Neill, C.: Hydrologic control of litter decomposition in seasonally flooded prairie marshes, Hydrobiologia, 286, 155-165, 1994.

Nuttle, W. K.: The extent of lateral water movement in the sediments of a New England salt marsh, Water Resour. Res., 24 2077-2085, 1988.

Nyman, J. A. and DeLaune, R. D.: $\mathrm{CO}_{2}$ emission and soil Eh responses to different hydrological regimes in fresh, brackish and saline marsh soils, Limnol. Oceanogr., 36, 1406-1414, 1991.

Nyman, J. A., DeLaune, R. D., Roberts, H. H., and Patrick Jr., W. H.: Relationship between vegetation and soil formation in a rapidly submerging coastal marsh, Mar. Ecol.-Prog. Ser., 96, 269-279, 1993.

Nyman, J. A., Walters, R. J., Delaune, R. D., and Patrick, W. H.: Marsh vertical accretion via vegetative growth, Estuar. Coast. Shelf S., 69, 370-380, 2006. 
Olsen, J. S.: Energy storage and the balance of producers and decomposers in ecological systems, Ecology, 44, 322-331, 1963.

Pozo, J. and Colino, R.: Decomposition processes of Spartina maritime in a salt marsh of the Basque Country, Hydrobiologia, 231, 165-175, 1992.

Reed, D. J.: The response of coastal marshes to sea-level rise: Survival or submergence?, Earth Surf. Processes, 20, 39-48, 1995..

Sutton-Grier, A. E., Keller, J. K., Koch, R., Gilmour, C., and Megonigal, J. P.: Electron donors and acceptors influence rates of decomposition in tidal marshes, Soil Biol. Biochem., 43, 15761583, 2011.

Turner, R. E.: Geographic variations in salt marsh macrophyte production: a review, Contrib. Mar. Sci, 20, 47-68, 1976.

Turner, R. E., Swenson, E. M., and Milan, C. S.: Organic and inorganic contributions to vertical accretion in salt marsh sediments, in: Concepts and Controversies in Tidal Marsh Ecology, edited by: Weinstein, M. P. and Kreeger D. A., Springer Netherlands, 583-595, 2000.

Valiela, I., Howes, B., Howarth, R., Giblin, A., Foreman, K., Teal, J., and Hobbie, J.: The regulation of primary production and decomposition in a salt marsh ecosystem, in: Wetlands: Ecology and Management, edited by: Gopal, B., Turner, R. E., Wetzel, R. G., and Whigham, D. E., Nat. Inst. Of Ecology, Jaipur, India, 151-168, 1982.
Voss, C. M., Christian, R. R., and Morris, J. T.: Marsh macrophyte responses to inundation anticipate impacts of sea-level rise and indicate ongoing drowning of North Carolina marshes, Mar. Biol., 160, 181-194, doi:10.1007/s00227-012-2076-5, 2013.

Weiss J. V., Emerson, D., and Megonigal, J. P.: Rhizosphere Iron(III) Deposition and Reduction in a Juncus effusus L.Dominated Wetland, Soil Sci. Soc. Am. J., 69, 1861-1870, 2005.

Weston, N. B., Vile, M. A., Velinsky, D. J., and Neubauer, S. C.: Accelerated microbial organic matter mineralization following saltwater intrusion into tidal freshwater marsh soils, Biogeochemistry, 102, 135-151, 2011.

Windham, L.: Comparison of biomass production and decomposition between Phragmites australis (common reed) and Spartina patens (salt hay) in brackish tidal marsh of New Jersey, Wetlands, 21, 179-188, 2001.

Wolf, A. A., Drake, B. G., Erickson, J. E., and Megonigal, J. P.: An oxygen-mediated positive feedback between elevated carbon dioxide and soil organic matter decomposition in a simulated anaerobic wetland, Global Change Biol., 13, 2036-2044, 2007.

Zedler, J. B. and Kercher, S.: Wetland resources: Status, trends, ecosystem services, and Restorability, Annu. Rev. Env. Resour., 30, 39-74, 2005. 